\title{
Unity: The Hall Mark of Islam
}

\author{
Dr. Sulaiman Sheu Adua ${ }^{1 *}$, Dr. Moshood Atanda Hadi ${ }^{2}$ \\ ${ }^{I}$ Department of Religions, History and Heritage Studies, Kwara State University, Malete \\ ${ }^{2}$ Department of Islamic Studies, Kwara State College of Education, Ilorin
}

*Corresponding Author: Dr. Sulaiman Sheu Adua, Department of Religions, History and Heritage Studies, Kwara State University, Malete

\begin{abstract}
The Islamic community in Nigeria and indeed world-wide is today bedeviled with the problem of disunity. The Nigerian sectors of the Ummah-shares a big portion of global disunity. Disunity robs Muslims of many things and puts them at a disadvantage. Worse still, it brings about the exact opposite of the kind of a community that Allah wants us to be (Q3: 103). More so, when the Hall Mark of Islam is Unity. What then is responsible? How could this problem be solved? The crux of this paper is to attempt answers to these questions and proffer possible solutions to disunity among the Muslims by upholding the mantra: "The Hall Mark of Islam is Unity”.
\end{abstract}

\section{INTRODUCTION}

Islam, a one time powerful religion that impacted on the whole worlds, is today at the crossroads. The Muslims today find themselves in a state of siege, gripped by ignorance and despondency, disunity, hopelessness and apathy, discord and disarray, struggling to get guidance from "those who have gone astray". One may ask the simple questions that started agitating the people's mind about the differences which are noted among some Muslim scholars, students or Ummah in general: Why can't we organize ourselves or carry out some of our actions uniformly? Why do we have these apparent differences in most of our festivals and so on. The answer is simple. Whatever appears to be disagreement among Muslims is a normal phenomenon. Islam has been the religion of a thinking people, i.e. the intellectuals; so, one is bound to find divergent opinions on some minor issues. As to the major practices, the Muslims are directed by Allah to be unanimous by holding the rope of Allah together "And hold fast by the covenant of Allah all together and be not disunited". (Q3: 103). It is against this background that this paper attempts to place on record that the Hall Mark of Islam is Unity.

\section{CONCEPT OF UNITY IN ISLAM}

Unity according to wiktionary.org is related to oneness, meaning: the state or fact of being one undivided entity or a single undivided thing, seen as complete in itself.

Brotherhood and unity in Islam are twin concepts that mutually reinforce each other to sustain a human model of the message of Tawhid on earth. Brotherhood ensures the bond of love, affection and concern in such a way that a believer sees another fellow believer the way he sees the image in the mirror that he faces: he would want for his fellow believer what he would want for that image in the mirror he faces, that is, himself. While brotherhood ensures the affectionate bond for the sake of the creator, unity ensures the pursuit of common goals of the Ummah that marches towards the fulfillment of the purpose of creation. The fraternal bond of believers according to El-Miskin (2009) is articulated by Allah Himself. It is manifested through practical correlatives of participation in common worship patterns backing up the divine articulation. It is also sustained through conscious efforts by believers to ensure the cohesion of the Ummah.

El-Miskin further elucidated that when Allah establishes the fraternal bond among believer (for instance in Qur'ãn 3: 10), it is meant to be a transcendental linkage that cuts across bounds; $\mathrm{He}$ explains that, while it is an admonishment, it is a declarative articulation not subjected to negotiation or compromise. As long as one is a believer, he must subscribe to this intra-Ummah fraternal bond. 
The declarative admonition of the Ummah's fraternal bond is reinforced by a qualitative appraisal of the Ummah's cohesive unity. The qualitative appraisal is encapsulated in a tripartite identity pattern that makes it the best community ever brought forth to this planetary entity, because its individual constituents and collective entity: (i) admonish that which is good (ii) prohibit that which is wrong, and (iii) believe in Allah. In his Summation, El-Miskin beliefs that this qualitative appraisal of the important bond constructed with the building blocks of faith that brings together diverse human elements within a single cohesive Ummah entity is both a reinforcement of the bond and a rationale that instills in the believer that this community called the Ummah is the best entity to belong to (Qur'ãn 3: 110).

\section{UNITY: THE HALL MARK OF ISLAM}

The Muslims in the world over believe in the oneness of Allah. So central is this fact to one's protestation of faith in Allah that the least derogation from it is an inexplicable sin that no extenuating circumstance can justify. The Qur'ãn says:

Allah forgiveth not that partners should be set up with Him, but $\mathrm{He}$ forgiveth anything else, to whom He pleaseth; to set up partners with Allah is to devise a sin most heinous indeed. (Q4: 48).

The Muslims are united in this belief. Even the weakest in faith who may be guilty of violation of Allah's command does not robustly impugn the oneness of Allah. Abdalati (1982) says:

...Islam is based on unshakable belief in the oneness and universality of God -the worshipped, the unity of mankind -the worshippers, and the unity of religion-the medium of worship.

For the Muslim, God is one, Eternal and universal. He is the creator of all men, the provider for all men, the judge of all men and the Lord over all men.

The institution of Salat (obligatory daily prayers) has the intendment of creating unity in the lives of Muslims. Apart from the uniformity in the way and manner prayers are observed, they make social intercourse possible and easy. In order to encourage such social intercourse, prayers said congregationally are rated twenty-seven times better and more rewarding than the ones said alone. Muslims thus meet congregationally in their different locality five times everyday of their lives. Abu Hurairah reported that:

The messenger of Allah found some people keeping away from congregational prayers and he said: "I intend to order someone to lead the people in prayer while I go to burn the houses of the people who do not join the congregational prayer". (Muslim).

The scholars are in agreement that it is in the pursuit of the expansion of the unity in Islam that on a weekly basis the mosques for the five daily prayers collapse into one bigger congregation for the Friday service. This is no mere ritual; it is to drive home the sameness and oneness of our humanity. The two Ids enable us to realise, on a greater scale, our ambition of a united humanity. The concourse provides not just the opportunity of meeting twice in a year, but summons attention to the fact that we are one humanity with a common destiny realizing the ultimate unity of Allah.

The Institution of Fasting provides a yet providential platform for the concept of Islamic unity. In addition to its spiritual dimension, fasting plays an equilibrating role in the life of the Ummah. The very rich and the penurious that are divinely juxtaposed in all human communities go through the same process of seeking to tame and domesticate the desire for food and drink. Whereas, for the poor, it is a continuation of the miserable existence to which they are used, the rich are reminded of the daily experience of the poor. When they thus become solicitous for the poor, subsequently, they help in redefining the common humanity of all.

The Zakah institution is yet a very unifying element in Islam. By Allah's design some person are hugely endowed with material opulence while others struggle to survive. This dichotomy is not just studious; it is equally purposive. Ours would have been a world saturated with some hubristic tendencies if resources with all existed in equipoise. It would have been a terrifying world to live in. Zakah provides the link. The giver gives without necessarily enslaving the receiver, while the receiver 
does not deify the giver. Each provides a basis for the fulfillment of Allah's command. Love in its undiluted and imperishable state becomes the by product of this exercise. The poor and the rich are united as both actors are witnesses of this divine process. Furthermore, the hemlock which is the desire to accumulate wealth and peculate what is collectively owned is cauterized. Little wonder that the stench of corruption (like the one in Nigeria today) is much more potent among those who do not have this Islamic value. Because of the role Zakah plays in cementing the relationship between members of the Islamic Ummah, it was a justificatory basis for Abubakr to go to war with those who saw the demise of the Prophet (S.A.W) as a golden opportunity to go back on the payment of Zakat.

Hajj is one of the noblest institutions that Allah has blessed humanity with. Its role in enhancing unity in Islam is incapable of any explication. It is simply an exhilarating experience. It is the only single event that brings people from different backgrounds and orientations together. It has the kind of crowd that no other gathering can boast of. Shariati (n.d) describes the Hajj thus:

In essence, Hajj is man's evolution towards Allah. It is a symbolic demonstration of the philosophy of creation of Adam... It may be stated that the performance of Hajj is a simultaneous show of many things; it is a "show of creation", a "show of history". A "show of unity", a "show of Islamic ideology" and a "show of the Ummah".

Hajj is a lesson in leadership. It tells us that a leader that is disdainful of the responsibilities that are a natural corollary of the privileges enjoyed, instigates and unmitigated humanitarian cataclysm. It instructs leaders to transform heterogeneous grounds into homogeneous ones. It is extrication from fragmentation and relativity to unity. In Hajj, one realizes the veracity of the oneness of mankind as stated in the Qur'ãn. One observes that the greed and lust of man are responsible for the desire to hold mankind divided. The Qur'ãn says:

Mankind was one single nation. And Allah sent messengers with glad tidings and warnings; and with them, He sent the Book in truth, to judge between people in matters where in they differed; but the people of the Book after the clear signs came to them, did not differ among themselves except through selfish contumacy. Allah by His Grace guided the believers to the truth... (Qur'ãn 2: 213).

The above institutional framework in Islam for unity, is no doubt a clear indication that the Hall Mark of Islam is unity, unity of faith, unity of action, unity of purpose and unity of thoughts.

\section{COG IN THE WHEEL OF UNITY AMONG MUSLIMS IN NigERIAN}

Asunogie Esq (2009) identified the following four major causes of disunity among Muslims: Lack of knowledge of the Din, Ego, tribalism and greed.

\subsection{Lack of Knowledge of the Din}

He observes that it is sad that a religion, to which scholarship is vital, is today populated by ignorant adherents. This vast army of ignorant followers has provided a source for recruiting those who fan the embers of disunity. On this, the holy Prophet (S.A.W) has provided a clear guidance when he says: "I am bequeathing two objects to you, and you will never go astray as long as you hold them together: the book of Allah and my Sunnah" (i.e. his tradition). It is from these two that Islamic law derives its primary source, the Qur'ann and Sunnah. The Muslims have a uniform application on these two first sources. The secondary sources of law are the Ijma' $a$ (consensus opinions of scholars) and Qiyaasi (the analogical deductions of the Muslim scholars. These are the areas where intellectual interpretation plays its role, and some people who cannot comprehend the reason for the divergent opinions of the Ulama ${ }^{c}$, feel there is disunity among the Ulama ${ }^{c}$ whereas, there is none at all.

In another approach, let us understand that Islamic Fiqh (jurisprudence) operates under what we know as Fareedat, Sunnah and Mustahab i.e. compulsory, necessary Sunnah of the Prophet and the preferable actions of the scholars. These are the normal applications on our Ibaadat i.e. act of worship. All Muslims are unanimous on the fareedat and Sunnah but they have different opinions in respect of Mustahab. Likewise, we have four orthodox Imams in Islam. They are Imam AbuHaneefa, ImamMalik, ImamShafi ${ }^{i}$ and Imam Hanbali (R.A.A), they only have divergent opinion on Mustahab issues, so it should not be construed that the Ummah is divided, as long as there is no controversy in the fundamental issues of faith. 


\subsection{Ego}

Ego is yet another problem. Every Muslim wants to be a Lord unto himself. The mushrooming of organizations in the name of Islamic propagation is a proof of this untoward development.

\subsection{Tribalism}

The North/South dichotomy is yet a serious problem threatening unity in Islam. The feeling of the superiority of one tribe over another is unhealthy. Owing to historical factors, the distribution of Muslims in the country is not even. Yet, they are found in every part of the country, among diverse ethnic groups: Hausa, Fulani, Kanuri, Yoruba, Nupe, Edo, Igbo etc. It is therefore a big mistake to claim that Nigeria is Muslim North and Christian South.

\subsection{Greed}

At the heart of the problem of unity in Islam is the unbridled greed on the part of those who masquerade as leaders.

\section{CONCLUSION}

From the foregoing discussion, it has been established that unity is primal to Islam and so it should be to the Muslim, both in his spiritual and mundane existence. Unity colours the hue of the belief system, constituting the onset and the outpost of his faith. It should be bored in mind that the injunction to remain united is strengthened by the prohibition of conflict among Muslims, as it would weaken them and lead to failure:

And obey Allah and His messenger (S.A.W) and do not dispute (with one another), lest you lose courage and your strength departs and be patient. Surely, Allah is with the patience. (Qur'ãn 8: 46).

Consequently, breaking up into factions (on Aqida) even after clear guidance from Allah had come, leads to shame in this world and eternal punishment in the hereafter.

And be not as those divided and differed among themselves after the clear proof had come to them. It is they for whom there is an awful torment. (Qur'än 3: 105).

Prophet Muhammad (S.A.W) provided the similitude of how united Muslims should be when he likened Muslims to a building, one part of which strengthens the other parts, thus keeping the whole building firmly in place. Another analogy that he gave is: "The likeness of Muslims regarding their mutual love and compassion is that of a human body: when a part is afflicted the rest of the body responds with sleeplessness and fever". (Abdul, 1980).

Therefore, Muslims wherever they are, irrespective of the sects, society or organization they belong, must remain united. They must always remember that "the Hall Mark of Islam is Unity". However, the unity that Muslims are required to foster is for a good righteous cause, not that of aggression or injustice against others:

...Do not let your wrath against those who have barred you from the Holy Mosque move you to commit acts of aggression; rather, help one another in furthering virtue and God consciousness, do not help one another in sin and transgression. (Qur'ãn 5: 2).

So, the call for Muslim unity should not be seen by anyone as threatening to them or rather be toyed with by any group (Muslims or non-Muslims alike). On the contrary, the unity of Muslims, whether within Nigeria or beyond, is in the interest of all Muslims and non-Muslims alike.

\section{RECOMMENDATIONS}

For the Muslim Community to realize the goal of unity, for them to be united and remain formidable the following recommendations would need to be applied.

- Placing a lot of emphasis on exploring truly common concerns, rallying points and goals. Rallying around common ideals, admonishment to the Ummah to hold on collectively to the common faith symbolized by the rope of Allah (Qur'ãn 3: 103), searching for common rallying 
points and, as much as one can, avoiding disagreements, is a vital instrument of promoting transcendental ideals of brotherhood and unity.

- Muslims should consciously maintain a large heart in themselves in such a way that good intention (or husn-al-zann) should be presumed in interacting with fellow believers. A good stock of husn al-zann will allow one to give the benefit of the doubt to the other.

- Suppressing Negative Impulses while relating to other brothers so that a vicious cycle of negatively impulsive responses are not met with similar counter responses to threaten the cohesiveness of believers who must be allies of one another promoting virtuous goals. Suppression of such angry impulses and forgiving the other are indeed ideal formulae for attaining forgiveness (Kazmul ghaiz and afwu an-nnas as they are described in Qur'ãn 3: 134)

- Conducting counseling sessions (or nasiha) in an emotionally dispassionate manner. Dispassionate, calm and kindly presented good counsel should always replace angry challenge, condemnation and denunciation. The famous story of the handling of the Bedouin who urinated in the Mosque during the time of the Prophet (S.A.W) is a universal and permanent model of handling people in accordance with their limitations until they learn. Indeed, the prophet also said on another occasion: "Speak to people in accordance with their perception". (Khatibu nnasa ala qadri uqulhim) (Ibn Hisham n.d.). This technique of affectionate and kind counsel even to an erring brother sustains cohesion among believers for hard heartedness disperses believers (Qur'ãn 3: 159).

- Every Muslim irrespective of their Creed (Aqida) should remember that Allah who created the whole universe knows what $\mathrm{He}$ has brought into existence. If $\mathrm{He}$ had wanted he would have made us one without any differences. He alone nurtures and controls the affairs of all things including human beings. He has given mankind the chief source of law i.e. the Qur'ãn, to govern the Muslim society. Anybody who submits to Allah has no choice except to follow the Qur'ãn in words and actions and as such, there is need for uniformity in all Qur'ãnic directions, because "the hall mark of Islam is Unity".

\section{REFERENCES}

[1] Abdullahi, H. (1982). The Family Structure in Islam. Lagos: Islamic Publication Bureau.

[2] Abdul, M.O.A. (1980). Selected Traditions of Al-Nawawi, Lagos: Academy Press.

[3] Ali, Y.A. (1975). The Holy Qur'an(Text, Translation and Commentary). Leicester: Islamic Foundation.

[4] Asunogie, N. Esq. (2009). "Unity in Islam". In Jimoh, S.A. (Ed.) Unity and Uniformity among Muslims: Some Contemporary Imperatives. Ilorin: Unilorin Press.

[5] El-Miskin, T. (2009). "Forging Islamic Brotherhood and Unity: Towards Transcendental Ideals for the Ummah's Cohesion" in Jimoh, S.A. (Ed.)Unity and Uniformity among Muslims: Some contemporary Imperatives. Ilorin: Unilorin Press.

[6] Shariati, A. (n.d). Hajj. Lagos: Islamic Publication Bureau.

[7] Wiktionary.org. The English Dictionary $3.0 \mathrm{http} . / /$ wikitionary.org.

[8] Ibn Hisham (n.d). Sirat Rasul Allah Vol. 1 Cairo: M.A. Subayt.

Citation: Dr. Sulaiman Sheu Adua, Dr. Moshood Atanda Hadi. "Unity: The Hall Mark of Islam". International Journal of Humanities Social Sciences and Education (IJHSSE), vol. 7, no.1, 2020, pp. 37-41. doi: http://dx. doi.org/10.20431/2349-0381.0701004.

Copyright: (C) 2020 Authors. This is an open-access article distributed under the terms of the Creative Commons Attribution License, which permits unrestricted use, distribution, and reproduction in any medium, provided the original author and source are credited. 